\title{
SUSCEPTIBILITY OF CLINICAL ISOLATES OF Bacteroides fragilis GROUP STRAINS TO CEFOXITIN, CEFOPERAZONE AND TICARCILLIN/CLAVULANATE
}

\author{
Arnaldo Aires PEIXoto JúniOR(1), Márcia Maria de Negreiros P. ROCHA(2), José Luciano Bezerra MOREIRA(2) \& Cibele Barreto Mano de CARVALHO(2)
}

\begin{abstract}
SUMMARY
A total of 40 strains of the B. fragilis group was isolated from clinical specimens in two hospital centers in Fortaleza from 1993 to 1997. The most frequently isolated species was Bacteroides fragilis (19 strains) and most isolates came from intra-abdominal and wound infections. The susceptibility profile was traced for cefoxitin, cefoperazone and ticarcillin-clavulanate by using the agar dilution reference method. All isolates were susceptible to ticarcillin-clavulanate $(128 / 2 \mu \mathrm{g} / \mathrm{ml})$. Resistance rates of 15 and $70 \%$ were detected to cefoxitin $(64 \mu \mathrm{g} / \mathrm{ml})$ and cefoperazone $(64 \mu \mathrm{g} / \mathrm{ml})$, respectively. Such regional results permit a better orientation in choosing this group of antibiotics for prophylaxis and therapy especially in relation to cefoxitin, which is frequently used in the hospital centers studied.
\end{abstract}

KEYWORDS: Bacteroides fragilis group; $\beta$-lactam; Antimicrobial resistance; Anaerobic bacteria.

\section{INTRODUCTION}

$\beta$-lactam antibiotics are critical agents in the treatment of anaerobic infections. Research from the 1970s showed that most anaerobes including the Bacteroides fragilis group and other Bacteroides strains were susceptible to penicillin $\mathrm{G}$, ampicillin and amoxicillin ${ }^{13}$. From the 1980 s on, resistance to penicillin started to be detected especially among Fusobacterium and Clostridium strains ${ }^{10}$.

The Bacteroides fragilis group are the most frequently anaerobic bacteria isolated from human infections and the most resistant to betalactam antibiotics. More than $90 \%$ are resistant to penicillin $\mathrm{G}$ and derivatives. Inside the group of cephalosporins, the most active are cefoxitin, cefotetan and ceftizoxime. The third generation cephalosporins, cefotaxime, cefoperazone and ceftriaxone present more activity than those of first generation to this bacterial group but high proportions of resistance varying between 30 and $60 \%$ have been found. The monobactam aztreonam has poor activity against anaerobes and is not indicated in the treatment of anaerobic infections. Carbapenens (imipenem and meropenem) and combinations of a $\beta$-lactam drug plus a $\beta$-lactamase inhibitor show, at present, the best activity against the $B$. fragilis group ${ }^{10}$.

Considering the great importance of the $B$. fragilis group, as well as the large use of the $\beta$-lactam antibiotics in human infections, the present study had as purposes, to determine the $B$. fragilis group susceptibility profiles to cefoxitin, cefoperazone and ticarcillin-clavulanate.

\section{MATERIAL AND METHODS}

\section{Bacterial strains}

A total of 40 strains were isolated from non-duplicate clinically significant isolates collected from 1993 to 1997 at two hospitals in Fortaleza/CE (Hospital Universitário Walter Cantídio -14 strains- and Instituto Dr. José Frota -26 strains). The anaerobes tested were $B$. fragilis group species as follows: B. fragilis (19), B. distasonis (6), B. ovatus (4), B. caccae (4), B. thetaiotaomicron (3), B. uniformis (2), B. vulgatus (1) and Bacteroides sp (1). Most isolates came from intra-abdominal and wound infections and more than half of the isolates were from surgical ward patients (Table 1). The specimens were plated onto Bacteroides Bile Esculin agar and phenylethyl alcohol agar (supplemented with 5\% defibrinated sheep blood and menadione $10 \mu \mathrm{g} / \mathrm{ml}$ ). They were incubated at $37{ }^{\circ} \mathrm{C}$ for $48 \mathrm{~h}$ in anaerobic jars. The anaerobic environment was obtained using commercially available gas generator envelope for anaerobiosis (DIFCO). Suspect organisms were transferred to Brain Heart Infusion broth (DIFCO) (supplemented with hemin solution $5 \mu \mathrm{g} / \mathrm{ml}$ and menadione $10 \mu \mathrm{g} / \mathrm{ml}$ ) and were identified by established methodology ${ }^{13}$. The strains were maintained at $-15{ }^{\circ} \mathrm{C}$ in BHIs medium with $20 \%$ glycerol until the susceptibility tests could be done.

\section{Antimicrobial susceptibility testing}

All the strains were tested for susceptibility to cefoxitin (Merck Sharp

(1) Bolsista do CNPq do Departamento de Patologia e Medicina Legal/UFC, Fortaleza, CE, Brasil

(2) Departamento de Patologia e Medicina Legal (DPML), UFC, Fortaleza, CE, Brasil

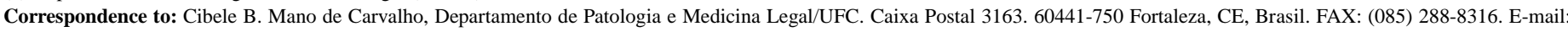
cbmc@secrel.com.br 
\& Dhome, Rahway, NJ), cefoperazone (Sigma Chemical CO, St Louis, MO) and ticarcillin-clavulanate (SmithKline Beecham). Antimicrobial susceptibility tests were performed by the agar dilution method as standardized by the National Committee for Clinical Laboratory Standards (NCCLS) using Wilkins-Chalgren agar ${ }^{11}$. The agar dilution tests plates were inoculated with a Steers replicator and all the procedures followed the recommendation of the NCCLS manual. Reference strains of B. fragilis (ATCC 25285) and B. thetaiotaomicron (ATCC 29741) were included in each experiment to assess the reliability of the method. Resistance was defined as follows: MIC $\geq 64 \mu \mathrm{g} / \mathrm{ml}$ for cefoperazone; $\mathrm{MIC} \geq 64 \mu \mathrm{g} / \mathrm{ml}$ for cefoxitin and MIC $\geq 128 / 2$ for ticarcillin-clavulanate.

\section{RESULTS}

40 strains from the Bacteroides fragilis group were isolated. Most of the species were $B$. fragilis, with a total of 19 samples. The sources of the specimens from where the $B$. fragilis group organisms were isolated are detailed in Table 1.

Table 1

Sources of specimens from which $B$. fragilis group species were isolated

\begin{tabular}{lcc}
\hline SOURCE & ISOLATES No. & $\%$ \\
\hline Intra-abdominal infections & 17 & 42.5 \\
Infected wounds & 7 & 17.5 \\
Soft tissue infection & 5 & 12.5 \\
Chronic otitis media & 5 & 12.5 \\
Blood & 1 & 2.5 \\
Pelvic inflammatory disease & 1 & 2.5 \\
Miscellaneous & 4 & 10 \\
\hline Total & 40 & 100 \\
\hline
\end{tabular}

From the tested antibiotics and combinations, ticarcillin-clavulanate was the most effective. All the strains were susceptible to this association with a CIM50 of $4 \mu \mathrm{g} / \mathrm{ml}$ and CIM90 of $32 \mu \mathrm{g} / \mathrm{ml}$. Cefoxitin showed relatively good activity with a moderate resistance rate of $15 \%$ (Table 2) for the tested strains; a MIC50 of $16 \mu \mathrm{g} / \mathrm{ml}$ and a MIC90 of $64 \mu \mathrm{g} / \mathrm{ml}$ were observed for this antibiotic. Cefoperazone did not show any satisfactory activity against the tested microorganisms. A $70 \%$ resistance to this drug (Table 2) and a MIC50 of $64 \mu \mathrm{g} / \mathrm{ml}$ and a MIC90 >256 $\mu \mathrm{g} /$ ml were observed.
From the strains of the Bacteroides fragilis group isolated, the $B$. fragilis species was more susceptible to $\beta$-lactam antibiotics than Bacteroides non-fragilis strains (Table 2).

\section{DISCUSSION}

The discovery of the antibiotics, the rising of vaccines, the recognition of the importance of feeding and sanitary education as promoters of health and human expectancy as well as the advances in microbiology, concerning the techniques of isolation and bacterial identification, provided a change of agents involved in human infections, from classical pathogens of exogena origin to opportunist pathogens, components of normal human microbiota ${ }^{8}$.

Anaerobic bacteria are the predominant microorganisms in many human anatomic sites thus, taking part in numerous processes as opportunists. The B. fragilis group, the Gram negative pigmented bacilli, F. nucleatum, C. perfringens, C. ramosum and Peptostreptococcus gathered as a whole, are responsible for half to $2 / 3$ of the clinically significant isolates of anaerobic bacteria. The $B$. fragilis group is the most frequent isolate from infectious processes and within this group, B. fragilis and B. thetaiotaomicron are the ones with major clinical implications ${ }^{13}$.

Among the three $\beta$-lactam drugs tested in this study, the association ticarcillin-clavulanate was the most active agent against the $B$. fragilis group organisms. Ticarcillin-clavulanate resistance has been reported, and between 1988 and 1998, in the USA, France and Canada, a low resistance rate was observed, ranging from 0.2 to $1.7 \%^{2,4,5,12}$.

The resistance to cephalosporins, especially to cefoxitin, the most active in the group against the $B$. fragilis group has varied among the species tested and hospitals studied. However, it is important to remember that the methodology and the choice for critical concentration, as well as, the selection of tested species are important determinants of this variability. In the hospitals researched, cefoxitin is one of the antibiotics chosen for the treatment of anaerobic infections, especially in surgical wards from where most of the clinical specimens were sent. Resistance rate of $15 \%$ to cefoxitin was detected. In the last two decades, in the USA, France, Canada, New Zealand, Spain, Italy and Brazil, rates of resistance to cefoxitin that varied between 1 and $26 \%$ were reported w $^{1,3,4,5,6,}$ 9,12 .

Third generation cephalosporins, as cefoperazone, are not chosen in empirical therapy of infections by the Bacteroides fragilis group because

Table 2

Resistance rates of $B$. fragilis group species

\begin{tabular}{llll}
\hline Antimicrobial (breakpoint) & $\begin{array}{l}\text { B. fragilis group } \\
(\mathrm{n}=40)\end{array}$ & $\begin{array}{l}\text { B. fragilis } \\
(\mathrm{n}=19)\end{array}$ & $\begin{array}{l}\text { Bacteroides non-fragilis* } \\
(\mathrm{N}=21)\end{array}$ \\
\hline Cefoxitin $(64 \mu \mathrm{g} / \mathrm{ml})$ & $6(15 \%)$ & 0 & $6(28 \%)$ \\
Cefoperazone $(64 \mu \mathrm{g} / \mathrm{ml})$ & $28(70 \%)$ & $11(58 \%)$ & $17(81 \%)$ \\
ticarcillin/ clavulanate $(128 / 2 \mu \mathrm{g} / \mathrm{ml})$ & 0 & 0 & 0 \\
\hline
\end{tabular}

*B. thetaiotaomicron, B. distasonis, B. ovatus, B. uniformis, B. caccae, B. vulgatus and Bacteroides sp. 
of high risk of resistance. In our study, a percentage of $70 \%$ of resistance to this antimicrobial was found.

It has been reported that $B$. fragilis species is the most susceptible to most $\beta$-lactam antibiotics, while the rate of resistance is considerably higher among the other species of this group. It has also been reported that most of the resistant strains belong to the $B$. thetaiotaomicron, $B$. ovatus and $B$. distasonis species and are producers of $\beta$-lactamases. It is well known that Bacteroides fragilis and related species produce several kinds of beta-lactamases such as oxyiminocephalosporinase, penicillinase, and metallo-beta-lactamase. In relation to the beta-lactams tested in this study and the percentage of resistance among the various species of the $B$. fragilis group, other studies of in vitro activities of beta-lactams for Bacteroides fragilis group are similar to those reported here.

FINEGOLD et ll $^{7}$ have pointed out chloramphenicol, imipenem, combination of beta-lactam drugs and beta-lactamase inhibitors and metronidazole as drugs of choice for the $B$. fragilis group infections therapy. They suggest that drugs with lesser activity, as cefoxitin and clindamycin, may be very useful in patients who are not seriously ill or in situations where susceptibility to these agents can be demonstrated in vitro.

We conclude from our study that:

- The level of resistance to cefoxitin may reflect the use of this drug in the centers studied since this antimicrobial is not routinely administrated to outpatients.

- Periodic studies of the Bacteroides fragilis group resistance are essential in order to evaluate the susceptibility patterns which might influence the choice of empirical therapy.

\section{RESUMO}

\section{Sensibilidade à cefoxitina, cefoperazona e ticarcilina-ácido clavulânico de cepas do grupo Bacteroides fragilis isoladas de espécimes clínicos}

Um total de 40 cepas do grupo $B$. fragilis foi isolada de espécimes clínicos em dois centros hospitalares de Fortaleza no período de 1993 a 1997. A espécie mais frequentemente isolada foi Bacteroides fragilis (19 cepas) tendo a maioria dos microrganismos sido isolada de infecção intra-abdominal e ferida cirúrgica infectada. Foi traçado o perfil de sensibilidade à cefoxitina, cefoperazona e associação ticarcilina-ácido clavulânico, utilizando-se o método de referência de diluição em ágar. Todas as espécies testadas apresentaram sensibilidade à ticarcilina-ácido clavulânico $(128 / 2 \mu \mathrm{g} / \mathrm{ml})$. Percentuais de resistência de 15 e $70 \%$ foram detectados para cefoxitina $(64 \mu \mathrm{g} / \mathrm{ml})$ e cefoperazona $(64 \mu \mathrm{g} / \mathrm{ml})$ respectivamente. A espécie $B$. fragilis apresentou os menores percentuais de resistência quando comparada com as demais espécies do grupo. Estes resultados regionais permitem uma melhor orientação na escolha deste grupo de antibióticos, para profilaxia ou terapêutica, principalmente com relação à cefoxitina que é frequentemente empregada nos centros hospitalares estudados.

\section{ACKNOWLEDGEMENTS}

We thank Antonio Jaldir G. Vieira for technical help.

\section{REFERENCES}

1. BOROBIO, M.V.; PASCUAL, A.; DOMINGUEZ, M.C. et al. - Evolution of the antimicrobial susceptibility of B. fragilis group at the University Hospital of Seville (Spain) between 1977 and 1995. Int. J. Antimicrob. Agents, 7: 1-7, 1996.

2. BOURGAULT, A.M.; LAMOTHE, F.; HOBAN, D.J. et al. - Survey of Bacteroides fragilis group susceptibility patterns in Canada. Antimicrob. Agents Chemother., 36: 343 $347,1992$.

3. CARVALHO, C.B.M.; MOREIRA, J.L.B. \& FERREIRA, M.C.S. - Survey of Bacteroides fragilis group susceptibility patterns in Brazil. Int. J. Antimicrob. Agents, 8: 115 120, 1997.

4. CUCHURAL Jr, G.J.; TALLY, F.P.; JACOBUS, N.V. et al. - Susceptibility of the Bacteroides fragilis group in the United States: analysis by site of isolation. Antimicrob. Agents Chemother., 32: 717-722, 1988.

5. CUCHURAL Jr, G.J.; TALLY, F.P.; JACOBUS, N.V. et al. - Comparative activities of newer $\beta$-lactam agents against members of the Bacteroides fragilis group. Antimicrob. Agents Chemother., 34: 479-480, 1990.

6. DE ALMEIDA, A.E.C.C. \& UZEDA, M. - Susceptibility to five antimicrobial agents of strains of the Bacteroides fragilis group isolated in Brazil. Antimicrob. Agents Chemother., 31: 617-618, 1987.

7. FINEGOLD, S.M.; BARON, E.J. \& WEXLER, H.M. - A clinical guide to anaerobic infections. Belmont, Star Publishing, 1992.

8. GONÇALVES, A.J.R. - Mudanças de padrões epidemiológicos e clínicos das doenças infecciosas nos últimos 35 anos. J. bras. Med., 68: 19-37, 1995.

9. HENDERSON, G.; GARNER, J. \& MORRIS, A. - Antimicrobial susceptibility of anaerobic bacteria in Auckland 1987-90. N. Z. med. J., 105: 11-12, 1992.

10. JOHNSON, C.J. - Susceptibility of anaerobic bacteria to $\beta$-lactam antibiotics in the United States. Clin. infect. Dis., 16: 371-376, 1993.

11. NATIONAL COMMITTEE FOR CLINICAL LABORATORY STANDARDS - Methods for antimicrobial susceptibility testing of anaerobic bacteria. 4. ed. Wayne, NCCLS, 1997. (NCCLS document M11-A4).

12. PATEY, O.; VARON, E.; PRAZUCK, T. et al. - Multicentre survey in France of the antimicrobial susceptibilities of 416 blood cultures isolates of the Bacteroides fragilis group. J. Antimicrob. Chemother., 33: 1029-1034, 1994.

13. SUMMANEN, P.; BARON, E.J.; CITRON, D.M. et al. - Wadsworth anaerobic bacteriology manual. 5. ed. Belmont, Star Publishing, 1993.

14. SUTTER, V.L. \& FINEGOLD, S.M. - Susceptibility of anaerobic bacteria to 23 antimicrobial agents. Antimicrob. Agents Chemother., 10: 735-752, 1976.

Received: 21 December 1999

Accepted: 03 April 2000 